\title{
Seasonal changes in Porteresia coarctata (Tateoka) beds along a subtropical coast
}

\begin{abstract}
Shoot density, standing crop (above- and below-ground biomass) and habitat of salt marsh grass Porteresia coarctata were investigated along the coast of Bakkhali estuary, Cox's Bazar, Bangladesh from January to December 2006. Shoot density of P. coarctata was influenced by season and was found to be higher (>2 500 shoots $/ \mathrm{m} 2)$ in post-monsoon and minimal in monsoon season; plants were particularly active in vegetative propagation during premonsoon. Above-ground biomass was greater along the protected coast compared with the exposed one in this estuary. Below-ground biomass was higher (7. 75-269. $53 \mathrm{~g} \mathrm{DW} / \mathrm{m} 2)$ than that above ground (2. 20-114. $75 \mathrm{~g} \mathrm{DW} / \mathrm{m} 2)$. Standing crops of P. coarctata showed a negative relationship $(\mathrm{R}=-0.77 ; \mathrm{P}<0.05)$ with sedimentation rate, while seasonal activity influenced sedimentation. The recorded sedimentation rate was lower $(6.09 \mathrm{mg} /(\mathrm{cm} 2 \cdot \mathrm{d}))$ in pre-monsoon and highest $(14.55 \mathrm{mg} /(\mathrm{cm} 2 \cdot \mathrm{d}))$ in monsoon season. The mean value of pore water salinity was higher (34. 25 \pm 5 . 05) during post-monsoon and lowest (18. $0 \pm 3.71)$ in monsoon season. The soil was sandy clay in this P. coarctata bed; it consisted of $86 \%$ sand, $13 \%$ clay and $1 \%$ silt. Soil organic matter dropped during the monsoon season $(0.78 \%-0$. $67 \%)$ and was highest $((2.17 \pm 1.42) \%-(2.3 \pm 1.47) \%)$ during post-monsoon, probably owing to accumulation of decomposed peat on the marsh surface. The mean pore water NH4-N concentration ranged from $2.44 \pm 1.65$ to $3.33 \pm 1.82 \mu \mathrm{g} / \mathrm{L}$, with a minimum air temperature of $22.09^{\circ} \mathrm{C}$ in post-monsoon and a maximum of $31.16^{\circ} \mathrm{C}$ in pre-monsoon. Variations of physico-chemical parameters in the soil, water, and climate governed biological parameters of P. coarctata in the Bakkhali estuary, and were comparable with estuarine environments elsewhere.
\end{abstract}

Keyword: Bangladesh; Porteresia coarctata; Salt marsh; Standing crop 